\title{
AFRICA IN RETROSPECT AND THE FUTURE: A STYLISTIC ANALYSIS OF DEVIATION AND PARALLELISM IN DIOP'S AFRICA
}

\author{
Charles Djorbua ${ }^{1 \mathrm{i}}$, \\ Isaac Danquah Darko², \\ Daniel Afrifa-Yamoah ${ }^{3}$ \\ ${ }^{1}$ Department of Languages, \\ Presbyterian College of Education, \\ Akropong Akuapem, \\ Ghana \\ ${ }^{2}$ General Studies Department, \\ Ghana Communication Technology University, \\ Ghana \\ ${ }^{3}$ Akenten Appiah-Menka University of \\ Skill Training and Development,
} Ghana

\begin{abstract}
:
Attention of language scholars has been shifting from the structural pattern of language to language as a functional unit given the change of interest from the form of a language to its function. This study presents a stylistic analysis of a well-known poem by David Diop "Africa" and analyses the unique role that language plays in projecting the central theme of the poem. The poem Africa is one of the poems that laments the ill treatments that Africa suffered in the hands of its colonialists, but which quickly paints a picture of hope for the continent. The researchers used foregrounding both as a stylistic theory and a method to analyse the poem so as to investigate how linguistic deviations and parallel structures are employed to project the central theme of the poem. The study revealed that both linguistic deviations and parallel structures as well as figurative expressions abound in the poem. These linguistic tools have, in no doubt, contributed immensely to the projection of the overall meaning of the poem - Africa's past glories, present predicaments of suffering and humiliation under colonialism and the future of hope and freedom embedded in Africa's rebirth. The study concludes that language and literary works contribute in a unified manner to expose the rots in society and then project a future of hope.
\end{abstract}

Keywords: stylistics, Africa, parallel structures, linguistic deviation, foregrounding

i Correspondence: email cdjorbua@yahoo.com 


\section{Introduction}

Language and literary work are seen to be two separate disciplines, but which are usually inseparable as literary work needs language to be able to function appropriately. Linguistics, the scientific study of language, is a rapidly growing discipline that is applied to the study of literary works. The growing nature of linguistics has opened new horizons in the field of literary criticism in the twentieth century leading to the advent of the Practical Criticism and the New Criticism originally in Western Europe and in the USA respectively, with principal focus on the form of the text. Linguistics, according to Halliday and Webster (2006), is the scientific study of human language as a system of human communication which encompasses different areas of investigation such as phonetics, phonology, morphology, syntax and semantics. The need to focus on how language or linguistics is used as a form of style in literary works to project meaning gave rise to the discipline referred to as stylistics.

\section{The Concept of Stylistics}

Stylistics is concerned with the analysis of style in a text using linguistics. Stylistics has everything to do with style in both literary and non-literary works. According to Abrams (1993), style is traditionally defined as "the manner of linguistic expression in prose or verse-it is how speakers or writers say whatever it is that they say." It simply refers to the way language is used in a context by a given person and for a given purpose. Different forms of style can be identified: style as individual, style as choice, style as deviation, style as situation, style as time/era and style as dress of thought (Fayele \& Ogili, 2016). Style as dress of thought, for example, postulates that thought and the way of thinking are two different entities. The thought may be the same but the way and manner it is processed or being thought may change according to the situation. That is, the words, phrases and language used to shape the thoughts may vary but which may not necessarily make any changes in what is being thought (Leech \& Short, 1981). Stylistics owes its origin to literary criticism which aims at studying text rather than the author of a text. In other words, stylistics analyses the linguistic contributions of a text that leads to its meaning. Stylistics is therefore the study of the ways in which meaning is created through language in literary as well as in other types of text (Nørgaard, Montoro, \& Busse, 2010). Widdowson (1975:4) defines stylistics as follows:

"By 'stylistics' I mean the study of literary discourse from a linguistic orientation and I shall take the view that what distinguishes stylistics from literary criticism on the one hand and linguistics on the other is that it is essentially a means of linking the two.....stylistics, however, involves both literary criticism and linguistics, as its morphological make-up suggests: the style component relating it to the former and the 'istics' component to the later."

Stylistics does not necessarily concern itself with coming up with new and startling interpretations of a text, unlike the traditional formalists approach, but rather tries to explain 
how our understanding of a text is achieved by looking at the details of the linguistic organization of the text and how the reader should interact with such linguistic organizations to make sense of the text (Short, 1995). Different types of stylistics abound: formal stylistics, cognitive stylistics, feminist stylistics, narrative stylistics, etc. According to Wales (2001), stylistics is a discipline that is mainly interested in describing the formal features of text and the functional significance of such features in relation to the interpretation of the text. Thornborrow and Wareing (1998: 4) identifies three key aspects of stylistics. These are:

- The use of linguistics (the study of language) to approach literary texts;

- The discussion of texts according to objective criteria rather than according to purely subjective and impressionistic values;

- An emphasis on the aesthetic properties of language (for example, the way rhyme can give pleasure).

The principles identified by Thornborrow and Wareing relate with the formalist approach to text analysis which serves as a bedrock for stylistics. Given all these strands from the various definitions and angles, stylistics is seen as an approach used to interpret text in which prominence is placed on language and style.

\section{The Poet and the Poem in Brief}

David Léon Mandessi Diop was born in Bordeaux, France to a Senegalese father and a Cameroonian mother in 1927. Diop was part of the Protest Period African writers. He was also a proponent of the Negritude, a political philosophy/literary movement which was a reaction to the French colonial administrative policy of assimilation. His poem "Africa" is a reflection of the values of the Negritude. He had his primary education in Senegal and Cameroon but spent the rest of his life in France. He developed interest for Africa especially during the World War II where he saw his fellow Africans fight and die for Europe. He afterwards began and intensified his criticism against the Europeans and their colonialism drive towards Africa. Diop died tragically in a plane crash in Senegal in 1960.

Poetry is a very rich means of bringing to the fore the reflections of society. The use of figurative language and other forms of imagery exposes the shortcomings of society and proffers to bring a change. This kind of literary genre forecasts the complex nature of life with regard to its varied shapes of representation (Ogundokun, 2013).

The poem "Africa" talks about Africa's past stories and glories, Diop's denunciation of the hypocrisy and wickedness of the colonial powers and then his vision for an independent Africa (Senanu \& Vincent, 1988). The poem begins on a note of reminiscence of Africa by Diop. He has never seen Africa but heard about it from songs sung by his grandmother. The symbolic use of "distant" in the poem emphasizes the notion of his remoteness from Africa yet his strong desire to pursue the course of Africa. The poem paints a vivid picture of Africa's past in which mention is made of the proud warriors who walked on its ancestral savannahs. The subsequent verses stress the irritating exploitation of the black people of Africa to the benefit of the colonialists: 

"Africa, tell me Africa
Is this your back that is bent
This back that never breaks under the weight of humiliation
This back trembling with red scars
And saying no to the whip under the midday sun."

The poet laments the pain and the humiliation that his people are enduring in their own land, but he urges them on to be strong and remain resolute as there is hope for them. Africa will spring up anew and take its rightful place:

\author{
"Impetuous child that tree, young and strong \\ That tree over there \\ That is your Africa springing up anew \\ Whose fruit bit by bit acquires \\ The bitter taste of liberty."
}

\title{
4. Works on Stylistics
}

Stylistics analysis of a text is relatively recent, in that, there are other older forms such as literary criticism, discourse analysis, etc. that were used to analyse text. Stylistics has, however, gained momentum given its relationship and interconnectedness with language and literature. Wulandari (2018) did a stylistic study in which language was used as a tool to describe how women were presented in a text by using the feminist stylistic approach. The research focused on how the position of women as actors was presented in the text using language. The study revealed that features describing women were different from those describing men. While body parts were used to describe women, men were described by their overall appearance. Jafaar (2014) analysed two poems from two different authors - E. E. Cummings and Seamus Heaney, using stylistics as a linguistic tool. The outcome of the study pointed to the fact that stylistics as a scientific tool is not only useful to those who are teaching but also to those studying English and language. Aside the literary competence gained, they also get linguistic skills that help enrich their linguistic competence. The study posits that based on linguistic evidence, stylistics analysis can help bring about logical and scientific understanding of a literary text. Fayele and Ogili (2016) did a study in which they employed both discourse and stylistics to analyse an excerpt of President Muhammadu Buhari's Democracy Day Speech of 2015 by pointing out their different, but related, methods of text analysis. The study revealed that stylistics is a tool used in discourse. Both discourse and stylistics analyses are viable means of analyzing text for interpretation.

This study has, as its main goal, to identify the role played by stylistics through the notion of foregrounding that is used in David Diop's poem "Africa" to project the central theme/message of the poem. It therefore seeks to analyse how linguistic deviations and parallel structures are employed to project the central message of the poem? 


\section{Theoretical Framework}

Stylistics as a discipline dwells on the theory of foregrounding to achieve its aim in analyzing text. Language is a major tool used in text and such language can be manipulated to produce a new perception or understanding of the text. A writer can exploit language in a different way that will depart from the norm. When that happens, the reader becomes amazed and gets a fresh awareness of the uniqueness of the language. It is of essence to note that language can be given an unusual treatment in the structure of a text, and this signals the notion of foregrounding. Leech (1969) opines that foregrounding is the giving of unusual prominence to one element or property of a text relative to other less noticeable aspects. According to Krishnamurthy (2010), foregrounding is a kind of patterning or shaping of a text which can occur on levels such as phonology, syntax, morphology and semantics and aims at achieving literary aesthetics. The idea of foregrounding is that some parts of text create more effect on the reader than others when it comes to interpretation. The textual parts of a poem or any other piece may be linguistically deviant or patterned in a way that will make them psychologically important for readers. Foregrounding is made up of two main components: deviation and parallelism.

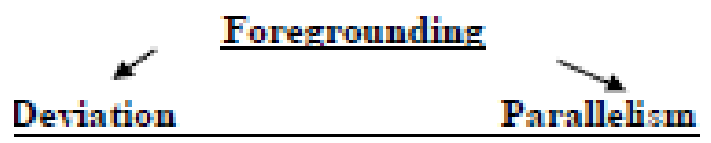

The Realization of Foregrounding (Leech, 1969:43)

\section{The Concept of Linguistic Deviations}

Deviation as a component of foregrounding is realized when there is a departure from the linguistic norm (style as deviation) for specific projections. Deviation can be effected in different forms, especially in poetry, with a few examples below (Leech, 1969):

- Lexical deviation: This is exemplified by using words in a special way such that they differ from the ordinary way of using them in order to express meaning and also add aesthetic value to the text.

- Semantic deviation: This is the kind of deviation where an ordinary simple word carries a special and astonishing meaning.

- Grammatical deviation: When a writer neglects the rules related to sentence structure by using tenses and other elements in the wrong way, grammatical deviation is in force.

- Morphological deviation is realized when some word formation structures used in the text defy the norm.

- Phonological deviation: This deviation comes into effect when sounds are created on purpose to give musical effect with consideration to rhyme.

- Graphological deviation: This is created when rules of punctuation are neglected. This could be exemplified by either writing without using punctuation or without using spaces, etc. This kind of deviation can also be identified through the use of words in italics, words that are underlined, bold letters, capital letters and so on. 
- Syntactic deviation: Sentence types and the effect that they create in a text is the focus of this deviation. A text may be composed of only simple sentences or a combination of simple, compound, complex and compound complex sentences. A text may also exhibit features of ellipsis, parataxis and hypotaxis.

These deviations are a way of creating abnormal patterns from the normal designs of language to give rise to the creation of different realities from the traditional norm or standard (Short, 1996). A glaring factor that is created is unconventionality which occurs as the result of the writer's collection of features among the range of linguistic items (Amjad, Ajmal, Rubab \& Naseer, 2020).

\section{The Concept of Parallelism}

Parallelism, the other component of foregrounding, is a complete and accurate adherence to linguistic rules rather than stepping out of the rules (Abdulmughni, 2019). It creates and reiterates the use of regular patterns for the achievement of a specific objective in the text. According to Balogun (2015), parallelism has its etymology from the Greek word Parallelos, which means placed side by side. It is directly in contrast with linguistic deviation. Parallelism is achieved through the repetition of lexical items and variation of linguistic features while keeping others constant. It may also feature in sentences, other structures and the meaning that resides in the poem as a whole. These parallel structures may sometimes appear to the reader through outright repetition but it could also be so dissimilar to the extent that they may be unobservable (Leech, 1969).

\section{Methodology}

This study explores the use of foregrounding as a stylistic theory and method to analyse the poem "Africa" by David Diop. This poem is made up of 23 lines, all packed in one stanza as its primary data. Specific foregrounding features such as linguistic deviation and parallelism are identified in the poem, which is the textual data, and are analysed to unravel how they contribute to project the central theme or message of the poem. This leads to a stylistic and linguistic analysis of the text to bring to the fore the impact of language and style in arriving at the meaning of the poem. The study examines how the poet has succeeded in presenting the theme or the central message using language in such a way that departs from what is recognized as the norm (deviation) or rather emphasizing regularity by creating linguistic patterns to help the course (parallelism). This poem was selected because it exhibits evidence of foregrounding such as phonological, morphological, syntactical, graphological and semantic features that help to project the overall meaning of the poem. 


\title{
9. Analysis and Discussion
}

This section deals with the analysis and discussion of the study. The first part handles the analysis and discussion of linguistic deviations while the second part looks into the parallel structures identified in the poem.

\section{Analysis of Linguistic Deviations}

\subsection{Phonological Structures}

At the phonological level, the poem exhibits the employment of alliterative words in its bid to put across its message. The use of alliteration is seen in lines 6, 7, 13 and 14 of the poem. For example:

\author{
" $\underline{B}$ ut your $\underline{\text { blood }}$

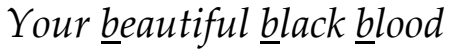 \\ Is this your back that is $\underline{b} e n t$ \\ This back that breaks under the weight of humiliation."
}

The use of alliteration helps to create rhythm and also gives musical effect to those lines of the poem and the poem as a whole. Apart from using the alliteration to create music and enhance the free flow of the message, it also creates a sense of contrast. The sound / $\mathbf{b} /$ is voiced but its repeated use in the poem does not really underscore its voiced nature. It rather depicts Africa under the weight of suffering and humiliation, but who has no voice to speak against the oppression. The repeated use of a voiced sound has been foregrounded probably to represent Africa's past heroic deeds but which are now silenced.

Another feature of interest in the poem is the use of long vowels in certain words such as:

$$
\begin{aligned}
& \text { work /ws:kl } \\
& \text { slavery /sleivaril } \\
& \text { field / fi:ld/ }
\end{aligned}
$$

Long vowels and diphthongs in speech indicate that the vowel component in the speech is stretched during pronunciation. These vowels have carefully and stylistically been chosen to stress the long suffering that the oppressors in the poem are being subjected to. Work and slavery have a similarity of relating to doing or exuding energy in some form and this is complemented by the notion of field which signify the receiving end of the energy exuded.

Under the phonological features, the poet resorted to the use of repetition copiously to drive home his message. Some of the lexical items repeated are:

"Africa, work, blood, sweat and slavery." 
Instances of repetition:

"Africa my Africa

Africa of proud .....

Africa of whom .....

The sweat of your work

The work of your slavery

The slavery of your children

Africa tell me Africa."

Repetition is the recurrence of sounds, words, phrases or an idea in a piece of literary work. The use of repetition in this manner gives rise to a typical rhythmic movement of the poem making it attractive to read. It also echoes the stream of pain that the oppressed is enduring in the hands of the oppressor. The persona's feeling of a once celebrated Africa that has been pushed into slavery is foregrounded through the use of repetition. The involvement of the words with long vowels in the repetition reinforces the seemingly protracted nature of the oppression being perpetrated.

\subsection{Morphological/Lexical Structures}

Most of the words used in this poem represent or depict three main themes: the first is the glorified past of Africa, then there are those which point to a period of oppression and then others which signify a rebirth of Africa. In the first instance, lexical items like Africa of proud warriors, Africa of whom my grandmother sings are chosen to foreground the heroic and past glories of Africa. These were cherished moments the persona reminisced and felt proud about. In the case of the second, lexical items such as sweat, slavery, breaks, weight of humiliation, back trembling, red scars, the whip under the midday sun bring to mind moments of suffering, difficulty and pain that characterize a period of imperialist domineering: the disappearance of the revered moments of Africa. These create an atmosphere of groom and hopelessness for the oppressed. However, this picture of imperialism through colonialism was dampened with the deployment of such words as white and faded flowers to signal the end of the oppressor and hence the possible end of the suffering of the oppressed. This leads to the third instance which signals a beacon of hope and a sense of rebirth of Africa initiated through the following lexical items: springing up anew, springing up patiently, fruits, tree, young, strong and taste of liberty. All these are words that herald futuristic liberation. The use of "impetuous child" cannot go unnoticed. It reinforces the liberation in the distance as the determined child will surely grow and assert his freedom.

\subsection{Syntactic Structures}

The sentence structure of the poem is varied. Some of the structures (lines) are actually phrases which also exhibit a run-on-line pattern: 
"The blood of your sweat

The sweat of your work

The work of your slavery

The slavery of your children."

These lines are stylistically woven to create that chain of flow that makes it possible for the poet to express the continuous suffering of the oppressed as revealed in the poem. Diop employed the use of anadiplosis as a pattern for the phrases. That is, the last word of each phrase becomes the word that begins the next phrase. These short phrases which are actually noun phrases inherently depict Africa and the absence of freedom that it is confronted with. It is also worth noting that the poem showcases instances of the use of compound sentences, even though such sentences are not marked by any end sign. For example:

"I have never known you

But your blood flows in me

This back trembling with red scars ...

But a grave voice answered me."

The fact that Africa, a continent, is suppressed by another continent is embedded in these compound structures. The poet used this style to underline the involvement of two entities in the battle of which Africa is the victim. The compound nature of some of the structures also highlights the connection between the present predicaments of Africa and the glimpse of hope that the future signals.

\subsection{Graphological Structures}

Punctuation is an important element in sentence structure construction, but Diop sharply violates this grammatical rule. The poem made up of 23 lines has only one full stop placed at the end of the entire poem. It is not for nothing that he adopts this style. Perhaps, the poet seeks to highlight the fact that there is only one thing on his mind and which is the freedom (rebirth) that awaits Africa in the end. All efforts should then be geared towards the achievement of that one cherished goal.

Note also the grammatical deviation in line 13 "is this your back that is bent". Here, the interrogative structure ends without a question mark. The tone is that of interrogation as it begins with an operator "is" resulting in a subject-verb inversion. However, the import of the poet does not seem to be asking a question but rather indicating and emphasizing the ordeal and humiliation that Africa is going through.

\subsection{Semantic Deviations}

Diop also relied on some figures of speech to make known his message. 


\subsubsection{Personification}

Personification is a kind of semantic deviation in which non-human things like animals, objects and ideas are given human qualities. The poem demonstrates the use of personification to bring to light the effect of the devastating and inhuman treatment of the black people in the hands of the colonialists. The personification I have never known you, and Your beautiful black blood that irrigates the fields are used to refer to Africa as though it were a human being. Even though Africa is not a human being, it represents the population of its continent. The persona personifies Africa to depict the pain that her people are being subjected to by the colonialists. This back trembling with red scars And saying yes to the whip under the midday sun is reaffirmation of the humiliation, pain, and suffering the people are enduring. Africa is personified to give a pictorial representation of the people on the continent that are being subjected to the suffering, pain and humiliation under colonialism.

\subsubsection{Symbolism}

Symbolism is a figure of speech in which an object, place, person or experience is used to stand for another thing, idea or concept. Field is used in the poem to represent the plantation farms of the colonialists on which the victim has been subjected to working incessantly. This is reinforced by a symbolic representation of Africa as a young tree that will grow and become strong. That tree young and strong; That tree over there is a symbol of hope that stands for Africa. This symbol of hope ushers Africa further into the future with resilience even though that liberty will not come on a silver platter. It must be fought for. The symbol of hope that the persona creates for Africa sharply contrasts with the dying image created about the colonialists Splendidly alone amidst white and faded flowers.

\subsubsection{Paradox}

Paradox is a form of semantic deviation in which two contradictory statements are placed side by side to present two contrasting aspects of the same entity to create a particular effect. In other words, such a statement can only be true if it is false. The poet in the last line of the poem makes use of paradox the bitter taste of liberty. This is established based on the fact that liberty is supposed to be freedom which should be devoid of any bitter experience but this is not the case as is demonstrated in this line. The linking of the freedom with bitter taste by the poet gives a signal of a future liberty that would surely be achieved but not without difficulty.

\subsection{Analysis of Parallel Structures}

Parallelism is a vital stylistic device that is used to promote collectiveness. There are some instances of parallel structures in the poem:

\footnotetext{
"The blood of your sweat

The sweat of your work

The work of your slavery"
} 
The poet willfully used anadiplosis to begin each of the phrases or expressions above. That is, the repetition of the last word in the previous phrase as the first word in the next phrase. The repeated nature of key words in these noun phrases goes a step further to buttress and emphasise the continues and repeated nature of the oppression visited on Africa.

\section{Summary of Findings and Conclusion}

This study employed stylistics as a linguistic tool to analyse David Diop's poem "Africa". The analysis of deviation and parallelism in the poem has demonstrated the relationship that exists between literary work and its effect on society as a mirror of reflection. Stylistic analysis is the review of language in a text in an attempt to unpack the linguistic effect on the weaving of the overall meaning of the message. Stylistics has helped to locate the constituent parts of this poem by David Diop. Through the stylistic theory of foregrounding, detailing linguistic deviations and parallel structures, the study has delved into the interpretation of the poem to unravel the central theme/message. The study has revealed that through linguistic foregrounding at the phonological, lexical, syntactic, graphological, figurative and parallel structure levels, the central message of the poem has been well presented. The theme of Africa's past glories, present predicaments of suffering and humiliation under colonialism and the future of hope and freedom embedded in Africa's rebirth has successfully been brought to light through the careful use of language. The poet laments the pain and the humiliation that his people are enduring in their own land, but he urges them on to be strong and remain resolute as there is hope for them. The study also revealed that through the use of stylistic tools of foregrounding, the right interpretation of a poem - text - can be reached even in the absence of a prior knowledge about the literary work and this has been achieved in this analytical work. The study concludes that poem as work of art is a potent means of bringing to light the negatives that are perpetrated in society through the stylistic application of language.

\section{Declaration on Conflict of Interests}

The authors declared no potential conflicts of interest with respect to the research, authorship and/or publication of this article.

\section{About the Authors}

Charles Djorbua is a Lecturer in the Department of Languages at the Presbyterian College of Education, Akropong Akuapem, Ghana. His research interest includes Language Policy, Language Variation, Sociolinguistics, English in Ghana, Discourse analysis and Stylistics.

Isaac Danquah Darko is a Lecturer in the General Studies Department at the Ghana Communication Technology University, Ghana. His research interest is in English Phonetics and Phonology, English in Ghana, Code-Switching, Second Language Acquisition, Language Variation and Academic Writing. 
Daniel Afrifa-Yamoah is a Lecturer in the Department of Interdisciplinary Studies at the Akenten Appiah-Menka University of Skill Training and Development, Ghana. His research interest is in Phonetics and Phonology, Intonation, Pronunciations and Transitivity.

\section{References}

Abdulmughni, S. A. S. (2019). Stylistics, Literary Criticism, Linguistics and Discourse Analysis. International Journal of English Linguistics; Vol. 9, No. 2.

Abrams, M. H. (1993). A Glossary of Literary Terms. (6th Edition). New York: Harcourt.

Amjad, M., Ajmal, M., Rubab, I. \& Naseer, A. (2020). Teaching English Poetry through Parallelism and Deviation for improving Students' Interpretative Skills. Journal of Critical Reviews, Vol 7, Issue 13

Balogun, S. (2015). A linguistic stylistic analysis of parallelism in inaugural speeches of presidents Barrack Obama and Goodluck Jonathan. An unpublished Master's Thesis at the Department of English, Ahmadu Bello University, Zaria.

Fayele, E. and Ogili, A. (2016). Discourse and Stylistics: Methods of Analysis. University of Abuja, Nigeria.

Halliday, M. A. K., \& Jonathan, W. (2006). On Language and Linguistics (p. vii.). Continuum International Publishing Group.

Jafaar, E. A. (2014). A Stylistic Analysis of Two Selected Poems. Journal of College of Education for Women/ P- ISSN: 1680-8738 Vol 25(1).

Krishnamurthy, S. (2010). The chutnification of English: An examination of the lexis of Salman Rushdie's Midnight's Children.

Leech, G. N. (1969). A Linguistic Guide to English Poetry, London: Longman.

Leech, G. \& Short, M. (1981). Style in Fiction. UK: Pearson Education Limited.

Montoro, R.; Busse, B. and Norgard, N. (2010). Key Terms in Stylistics. USA: Bloomsbury.

Ogundokun, S. A. (2013). Representations of nature in J. P. Clark's 'Night Rain': an eco-critical study. Global Journals of Arts Humanities and Social Sciences, 1(3): 20-28.

Senanu, K. E. and Vincent, T. (1988). A Selection of African Poetry. (2nd edn.). London: Longman

Short, M. (1995) In P. Verdonk \& J. J. Weber (eds.), Twentieth-century fiction from text to context. London: Routledge.

Short, M. (1996). Exploring the Language of Poems, Plays and Prose. London: Longman.

Thornborrow, J. \& Wareing, S. (1998). Patterns in language: an introduction to language and literary style. London: Routledge.

Wales, K. (2001). A dictionary of stylistics (2nd edn.; 1st edn. 1989). Harlow: Longman.

Widdowson, H. G. (1975). Stylistics and the Teaching of Literature. London: Longman.

Wulandari, S. (2018). A Feminist Stylistic Analysis in Laurie Halse Anderson's Novel 'Speak'. Thesis, University of Sumatera Utara.

Africa by David Diop (2021). Retrieved 6 August 2021, from https://allpoetry.com/poem/8562839-Africa-by-David-Diop 


\section{Appendix}

\section{Africa}

"Africa my Africa

Africa of proud warriors in ancestral savannahs

Africa of whom my grandmother sings

On the banks of the distant river

I have never known you

But your blood flows in my veins

Your beautiful black blood that irrigates the fields

The blood of your sweat

The sweat of your work

The work of your slavery

Africa, tell me Africa

Is this your back that is bent

This back that never breaks under the weight of humiliation

This back trembling with red scars

And saying no to the whip under the midday sun

But a grave voice answers me

Impetuous child that tree, young and strong

That tree over there

Splendidly alone amidst white and faded flowers

That is your Africa springing up anew

Springing up patiently, obstinately

Whose fruit bit by bit acquires

The bitter taste of liberty." 
Creative Commons licensing terms

Author(s) will retain the copyright of their published articles agreeing that a Creative Commons Attribution 4.0 International License (CC BY 4.0) terms will be applied to their work. Under the terms of this license, no permission is required from the author(s) or publisher for members of the community to copy, distribute, transmit or adapt the article content, providing a proper, prominent and unambiguous attribution to the authors in a manner that makes clear that the materials are being reused under permission of a Creative Commons License. Views, opinions and conclusions expressed in this research article are views, opinions and conclusions of the author(s). and European Journal of Literature, Language and Linguistics Studies shall not be responsible or answerable for any loss, damage or liability caused in relation to/arising out of conflicts of interest, copyright violations and inappropriate or inaccurate use of any kind content related or integrated into the research work. All the published works are meeting the Open Access Publishing requirements and can be freely accessed, shared, modified, distributed and used in educational, commercial and non-commercial purposes under a Creative Commons Attribution 4.0 International License (CC BY 4.0). 